\title{
ARTYKUtY
}

Klio. Czasopismo poświęcone dziejom Polski i powszechnym

PL ISSN 1643-8191, t. 43 (4)/2017, s. 47-68

(c) $($ (1) $\Theta$

http://dx.doi.org/10.12775/KLIO.2017.044

ANDRZEJ KAMIEŃSKI

\section{Kulisy kapitulacji wielkopolskiego pospolitego ruszenia pod Ujściem w 1655 roku}

\section{Behind the scenes of capitulation of Polish troops near Ujscie in 1655}

Streszczenie: Kapitulacja pospolitego ruszenia zgromadzonego pod Ujściem pod wodzą wojewody poznańskiego Krzysztofa Opalińskiego i wojewody kaliskiego Andrzeja Karola Grudzińskiego w celu obrony Wielkopolski przed Szwedami ma już pokaźną literaturę. Za głównych sprawców zdrady i oddania Wielkopolski pod protekcję króla szwedzkiego Karola X Gustawa uważano dotychczas magnackich dowódców, w szczególności Opalińskiego. Analiza zgromadzonego przeze mnie materiału źródłowego wykazała wszakże, iż odpowiedzialność za akt ujski należy rozłożyć solidarnie na wszystkie siły polityczne, zaczynając od króla Jana Kazimierza.

Kluczową rolę w demontażu organizacji obrony Wielkopolski przed Szwedami odegrali nieobecni pod Ujściem Leszczyńscy, przede wszystkim starosta generalny Wielkopolski i podskarbi wielki koronny Bogusław. Po dezercji Bogusława Leszczyńskiego ciężar przygotowań do odparcia najazdu szwedzkiego spoczął na Opalińskim i Grudzińskim. Obaj

* Instytut Historii PAN, Rynek Starego Miasta 29/31, 00-272 Warszawa, kamienski1934@onet.pl. 
wojewodowie starali się wywiązać z tego zadania, dążąc do zgromadzenia w pasie nadnoteckim jak największych sił zbrojnych. Szlachta, wyprawiwszy nad Noteć piechurów łanowych, nie spieszyła się jednak sama do chwycenia za broń, opóźniając całą akcję mobilizacyjną. Wydaje się, że to zachowanie szlachty w trakcie przygotowań do obrony oraz w przełomowych chwilach pod Ujściem utwierdziło Opalińskiego i Grudzińskiego w przekonaniu, że wszelki opór nie ma większego sensu.

Abstract: There are numerous publications concerning a capitulation of Polish troops under command of Voivode of Poznan Krzysztof Opalinski and Voivode of Kalisz Andrzej Karol Grudzinski near a village Ujscie. A main goal of this decision was to defend the Greater Poland against Swedish army. These two magnate leaders till nowadays were considered as main actors of this treason and putting the Greater Poland under a protectorate of Karol X Gustaw, the king of Sweden. However, analysis of new sources presented in this article allows us to conclude that responsibility for the actions near Ujscie should be divided equally among all political fractions, including the one headed by Jan Kazimierz, the king of Poland.

A main role in a deconstruction of a defence in the Greater Poland against Swedes was played by members of Leszczynski Family, who were not present in a camp near Ujscie, particularly by the general starosta of the Greater Poland and vice-treasurer of the Polish Crown, Boguslaw Leszczynski. After his desertion, Opalinski and Grudzinski had to overtake all preparations of the defence against Swedish invasion. Both of them tried to fulfil this task by gathering the most numerous troops possible in the area of river Notec. Unfortunately, most nobility indicated a fix number of soldiers, according to the size of their estate (Pol. piechota tanowa), and did not joined the army in person, what slowed down the whole mobilisation of the army. It seems that this attitude of nobility was the reason why Opalinski and Grudzinski were certain that no attempt or defence strategy has any sense and resulted in capitulation.

Słowa kluczowe: pospolite ruszenie; obrona Wielkopolski; kapitulacja pod Ujściem; wojna polsko-szwedzka

Keywords: Keywords: Polish troops, defence of the Greater Poland, capitulation near Ujscie, Polish-Swedish war 
W

konsekwencji sojuszu cara Aleksego Michajłowicza z Bohdanem Chmielnickim, w maju 1654 roku doszło do wybuchu wojny Rzeczypospolitej z Rosją i powstania drugiego obok Ukrainy teatru działań wojennych - na Litwie. Zantagonizowanemu z dworem królewskim hetmanowi wielkiemu litewskiemu Januszowi Radziwiłłowi nie udało się powstrzymać wojsk carskich, które w ciągu kilku miesięcy zajęły Dorohobuż, Dzisnę, Połock, Smoleńsk, Witebsk i Mohylew. Opanowanie linii Dźwiny przez Rosjan zagroziło poważnie szwedzkim posiadłościom w Inflantach i było jedną z przyczyn podjęcia przez nowego króla Szwecji Karola X Gustawa przygotowań wojennych. Tymczasem król Jan Kazimierz nie zdawał sobie sprawy z krytycznej sytuacji Rzeczypospolitej i zamiast szukać porozumienia na północy, podtrzymywał swe prawa dziedziczne do tronu szwedzkiego oraz pretensje do Inflant. Postawa polskiego króla, nadchodzące do Sztokholmu wieści o klęskach wojennych Rzeczypospolitej, rosnąca nad Wisłą anarchia wewnętrzna i powszechne niezadowolenie z rządów Jana Kazimierza utwierdzały Karola X Gustawa w jego planach interwencji po drugiej stronie Bałtyku. Postępy militarne cara Aleksego Michajłowicza przerwały wahania dworu sztokholmskiego, który zastanawiał się początkowo, czy uderzyć na Polskę, czy na Rosję. Celem przygotowywanej przez Sztokholm agresji stały się te ziemie Rzeczypospolitej, które nie znalazły się jeszcze pod okupacją obcych wojsk. Ich zajęcie przez Szwedów miało zapobiec, w mniemaniu Karola X Gustawa, nadmiernemu wzmocnieniu potęgi rosyjskiej kosztem słabnącego w szybkim tempie polsko-litewskiego kolosa ${ }^{1}$.

O planach wojennych Karola X Gustawa szybko został poinformowany lennik króla polskiego, elektor brandenburski Fryderyk Wilhelm. Już we wrześniu 1654 roku pojawił się u niego w Berlinie poseł szwedzki hrabia Christoph Karl Schlippenbach, który zwrócił się do władcy Brandenburgii-Prus z propozycją zawarcia szwedzko-brandenburskiego przymierza i udostępnienia Karolowi X Gustawowi pruskich portów w Piławie i Kłajpedzie. Elektor nie był jednak zainteresowany propozycją dostania się pod zwierzchnictwo szwedzkie i ociągał się z zajęciem jednoznacznej postawy.

${ }^{1}$ T. Nowak, Geneza agresji szwedzkiej, [w:] Polska w okresie drugiej wojny pótnocnej 1655-1660, t. 1, Warszawa 1957, s. 114-119. 
Zasłaniał się zobowiązaniami wynikającymi z układu lennego, podejmując jednocześnie rolę mediatora pomiędzy Rzeczpospolitą a jej wrogami²

Dwór warszawski nie zabiegał zbytnio o pomoc i pośrednictwo Hohenzollerna. Inaczej rzecz się miała z magnatami sąsiadującej z Marchią Wielkopolski. 25 grudnia 1654 roku starosta generalny Wielkopolski i podskarbi wielki koronny Bogusław Leszczyński poprosił elektora Fryderyka Wilhelma - „jako przyjaciela króla i Królestwa Polskiego” - o informacje na temat nieprzyjaznych kroków Szwecji względem Polski. W odpowiedzi udzielonej 4 stycznia 1655 roku Hohenzollern odesłał Leszczyńskiego do swojego radcy kameralnego, barona Władysława von Kurtzbacha-Zawadzkiego (Korzbok-Zawadzkiego), którego wyprawiał właśnie z poselstwem na dwór Jana Kazimierza ${ }^{3}$.

W drodze do Warszawy brandenburski radca odwiedził również innych wybitniejszych senatorów wielkopolskich. Najważniejszym rozmówcą Kurtzbacha-Zawadzkiego okazał się skonfliktowany z Janem Kazimierzem wojewoda poznański Krzysztof Opaliński. Poufne spotkanie z nim odbyło się w Sierakowie krótko przed 8 lutego 1655 roku, gdyż właśnie w tym dniu Opaliński podziękował elektorowi za otrzymane za pośrednictwem barona wiadomości i zapowiedział wysłanie do Berlina w celu kontynuowania rokowań swego „zaufanego przyjaciela”, spolonizowanego Austriaka, barona Johanna Ludwiga von Wolzogena ${ }^{4}$. Pertraktacje prowadzone nad Sprewą przez Wolzogena, znanego bardziej z dokonań filozoficznych i teologicznych aniżeli dyplomatycznych, nie przyniosły jednak żadnych rozstrzygnięć. Dotyczyły one przyjęcia przez elektora opieki nad Wielkopolską, ewentualnie zawarcia przez obie strony sojuszu wymierzonego przeciwko Szwedom. Tajni radcy brandenburscy w wydanym 15 lutego 1655 roku

${ }^{2}$ W. Arndt, Die Sendung des Grafen Schlippenbach zu Kurbrandenburg und Kursachsen im Jahre 1654, „Zeitschrift für Geschichte und Politik”, t. 5: 1888, s. 11-32; A. Kamieński, Stany Prus Książecych wobec rządów brandenburskich $w$ drugiej potowie XVII wieku, Olsztyn 1995, s. 55-56.

${ }^{3}$ Urkunden und Actenstücke zur Geschichte des Kurfürsten Friedrich Wilhelm von Brandenburg (dalej: UA), t. 7, wyd. B. Erdmannsdörffer, Berlin 1877, s. 359.

${ }^{4}$ Geheimes Staatsarchiv Preußischer Kulturbesitz (dalej: GStAPK) Berlin-Dahlem, I.HA, Rep. 9 (Polen) Nr 5 ee Fasz. 7 b, k. 2-2 v, K. Opaliński do elektora Fryderyka Wilhelma, Sieraków 8 II 1655 r. 
oświadczeniu nie zadeklarowali udzielenia jakiejkolwiek pomocy Wielkopolanom. Hrabia Georg Friedrich von Waldeck i Thomas von dem Knesebeck utrzymywali, że nie należy „pomagać ludziom, którzy nie potrafią sami sobie pomóc”. Sekundował im tajny radca Erasmus Seidel, przestrzegając przed zawarciem przymierza z Wielkopolską i wciągnięciem tą drogą Brandenburgii-Prus w konflikt zbrojny ze Szwecją. Nieco innego zdania był Lorenz Christoph von Somnitz, który uważał, że jeżeli w ogóle myśleć o sojuszu przeciwko Szwedom - to z całą Rzeczpospolitą, a nie z jedną jej prowincją. Największy znawca spraw polskich spośród tajnych radców, Johann von Hoverbeck nie podzielił tych opinii. Doradzał, żeby nie odrzucać definitywnie prośby Wielkopolan, lecz pozostawić im nadzieję. Postulował także konieczność wybadania, jakimi środkami wojskowymi i finansowymi dysponuje głowa opozycji wielkopolskiej - Krzysztof Opaliński

Elektor Fryderyk Wilhelm przychylił się do rad Hoverbecka i w odpowiedzi danej Opalińskiemu 17 lutego 1655 roku pochwalił wojewodę poznańskiego za czujność i przenikliwość polityczną, powstrzymując się przed konkretnymi obietnicami ${ }^{6}$. Chcąc wszakże zachować nić porozumienia z liderem wielkopolskiej opozycji, zapowiedział wysłanie do Sierakowa swego pełnomocnika, członka Tajnej Rady, Ottona von Schwerina, w celu dokładnego omówienia warunków przyjęcia protekcji brandenburskiej nad Wielkopolską, ewentualnie zawarcia sojuszu wymierzonego przeciwko Szwedom? .

Legacja Schwerina do Opalińskiego nie doszła do skutku, co było zapewne spowodowane chęcią zyskania na czasie, obawami przed reakcją Szwedów i przedwczesnym wiązaniem się z opozycją antykrólewską oraz wciąż niejasnym stanowiskiem Jana Kazimierza ${ }^{8}$. Misja dyplomatyczna Kurtzbacha-Zawadzkiego w Warszawie nie przyniosła spodziewanego skut-

${ }^{5}$ Ibidem, k. 3-4v (skrót: UA, t. 7, s. 361), Protokół z posiedzenia Tajnej Rady, b.m. 15 II 1655 r.

${ }^{6}$ GStAPK Berlin-Dahlem, I. HA, Rep. 9 (Polen) Nr 5 ee Fasz. 7 b, k. 13-15v, Elektor Fryderyk Wilhelm do K. Opalińskiego, Kölln nad Sprewą 17 II 1655 r.

${ }^{7}$ Ibidem, k. 5-7v, Memoriał elektora Fryderyka Wilhelma dla O. von Schwerina, posła do K. Opalińskiego, b.m. i d. [II 1655].

${ }^{8}$ M. Hein, Otto von Schwerina. Der Oberpräsident des Grossen Kurfürsten, Königsberg Pr. 1929, s. 67; K. Piwarski, Stosunki szwedzko-brandenburskie a sprawa polska w czasie 
ku. Oferta zapośredniczenia przez elektora Fryderyka Wilhelma pokoju między Rzeczpospolitą a Rosją nie została podjęta przez Jana Kazimierza. Żadnego wrażenia nie zrobiły na królu także ostrzeżenia Hohenzollerna przed zbrojeniami Szwedów i ich rychłym atakiem na Polskę. Ostatni na polskim tronie Waza zachowywał się wciąż beztrosko. Zaniepokojeni rozwojem wydarzeń Wielkopolanie - wojewoda poznański Krzysztof Opaliński i jego kuzyn wojewoda łęczycki Jan Leszczyński - przybyli na radę senatu, która odbyła się 12 marca 1655 roku w Warszawie, z konkretnymi żądaniami. Domagali się wraz z innymi senatorami zwołania sejmu i wysłania posłów pełnomocnych do Szwecji. I tym razem Jan Kazimierz potraktował te głosy lekceważąco, oświadczając Janowi Leszczyńskiemu sarkastycznie, że „nie taki Szwed straszny, jak go tchórze malują”" Wielkopolanie byli więc zdani tylko na siebie i nie mogli oglądać się dłużej na lekkomyślnego króla.

Nieco później Jan Kazimierz pogrążył się również w oczach Hohenzollerna. 1 maja 1655 roku wysłał do Berlina swego sekretarza Bartholda Rautenfelsa, dając elektorowi Fryderykowi Wilhelmowi pełnomocnictwo zawarcia pokoju ze Szwedami pod wygórowanymi warunkami, rozmijającymi się całkowicie z ówczesną sytuacją polityczną. Za zrzeczenie się praw do tronu szwedzkiego polski Waza żądał od Szwedów Inflant, 200 tys. talarów odszkodowania i pomocy wojskowej przeciwko Moskwie i Kozakom $^{10}$. Jan Kazimierz docenił zagrożenie szwedzkie wtedy, gdy było już za późno. Najwyższej rangi posłowie Rzeczypospolitej wyposażeni w pełnomocnictwo do zawarcia wieczystego pokoju, Jan Leszczyński i Aleksander Naruszewicz, wjechali uroczyście do stolicy Szwecji 5 lipca 1655 roku, sześć dni przed zaatakowaniem przez Karola X Gustawa Rzeczypospolitej i zajęciem przez jego armię inflancką Dyneburga ${ }^{11}$.

pierwszej wojny pótnocnej, [w:] Polska w okresie drugiej wojny pótnocnej 1655-1660, t. 1, s. 426.

${ }^{9}$ L. Kubala, Wojna szwedzka w roku 1655 i 1656, Lwów 1913, s. 31-35; A. Sajkowski, Krzysztof Opalinski wojewoda poznański, Poznań 1960, s. 220.

${ }^{10}$ UA, t. 7, s. 366-367, Instrukcja króla Jana Kazimierza dla B. Rautenfelsa, Warszawa 1 V 1655 r. Zob. też L. Kubala, Wojna szwedzka, s. 53-54; K. Piwarski, Stosunki szwedzko-brandenburskie, s. 426.

${ }^{11}$ L. Kubala, Wojna szwedzka, s. 64-69, 86; T. Nowak, Geneza agresji, s. 134-135. 
W zaistniałej w przededniu wojny szwedzkiej sytuacji magnaci wielkopolscy zaczęli z coraz większą otwartością szukać protekcji i opieki w najbliższym sąsiedzie - elektorze brandenburskim. Hohenzollern chciał teraz wzmocnić swoją pozycję przetargową wobec Szwedów przymierzem z Wielkopolską, aby wytargować od Karola X Gustawa jak największe korzyści. Musiał wszakże wysondować wcześniej, na jakie ustępstwa gotowa jest nie tylko tamtejsza elita polityczna, ale cała szlachta, dowiedzieć się, co można zyskać w zamian za „protekcję”. Okazja ku temu pojawiła się dopiero w końcu kwietnia 1655 roku. Pod wpływem groźnego wystąpienia prymasa Andrzeja Leszczyńskiego król Jan Kazimierz zgodził się w końcu na złożenie sejmu na 19 maja, który miał się zająć organizacją obrony, a więc podatkami i wojskiem. Poprzedziły go sejmiki przedsejmowe zwołane na 28 kwietnia $^{12}$.

Misja barona Kurtzbacha-Zawadzkiego na sejmik średzki ujawniła, że stanowisko szlachty wielkopolskiej było niemal zbieżne z poglądami tamtejszych magnatów zaangażowanych w porozumienie z Hohenzollernem. Szlachta prosiła bowiem o brandenburską pomoc wojskową i nie odrzuciła stanowczo warunków elektora, który chciał wprowadzić swoje oddziały do strategicznie położonych miejscowości w pasie pogranicznym oraz uzyskać od stanów wielkopolskich przynajmniej 12 talarów na żołnierza $^{13}$. 4 maja 1655 roku złożono na ręce Kurtzbacha-Zawadzkiego prośbę do elektora brandenburskiego, aby przysłał od dwóch do trzech tys. żołnierzy dla obsadzenia ważnych strategicznych przepraw od Noteci do Wisły, proponując zapłatę czterech talarów miesięcznie na każdego pieszego ${ }^{14}$. W ślad za tym skierowano do Fryderyka Wilhelma dwa listy, w których proszono Hohenzollerna o przyjęcie Wielkopolski pod brandenburską protekcję i opiekę. Ich autorami byli marszałek sejmiku średzkiego, sędzia

12 K. Jarochowski, Wielkopolska w czasie pierwszej wojny szwedzkiej od roku 1655 do 1657, [w:] idem, Zdobywcy i okupanci staropolskiego Poznania, Poznań 2007, s. 11; L. Kubala, Wojna szwedzka, s. 42-43.

${ }^{13}$ UA, t. 7, s. 362-354, Instrukcja dla W. Kurtzbach-Zawadzkiego posła elektorskiego na sejmik średzki, b.m. [13 IV 1655 r.].

${ }^{14}$ GStAPK Berlin-Dahlem, I. HA, Rep. 9 (Polen) Nr 5 ee Fasz. 7 b, k. 25-26; W. Kurtzbach-Zawadzki do elektora, Środa 24 IV/4 V 1655 r. 
ziemski wschowski Jan z Bukowca Szlichtyng ${ }^{15}$ oraz wojewoda poznański Krzysztof Opaliński ${ }^{16}$.

Zarówno magnaci, jak i wielkopolska szlachta chętnie widzieli w elektorze obrońcę prowincji. Zaufanie, jakim darzono Hohenzollerna, zostało jednak wkrótce podkopane w wyniku afery związanej z pojmaniem oficera brandenburskiego Jacoba Holsta. Zatrzymany przez Polaków w połowie kwietnia 1655 roku w okolicach Czarnkowa oficer miał przy sobie nie tylko plany twierdz w Toruniu i Grudziądzu oraz opisy wszystkich przepraw na Noteci i Wiśle, ale również szczegółowy przegląd poznańskich umocnień, aż po najmniejsze furtki w murach miejskich, wykaz słabych punktów obwarowań, a także dane dotyczące szerokości i głębokości Warty w Poznaniu ${ }^{17}$. Jeszcze na początku maja 1655 roku Holst uchodził za szwedzkiego szpiega. Później jednak Polacy dowiedzieli się, że jest inżynierem z garnizonu twierdzy w Kostrzynie nad Odrą, wysłanym na przeszpiegi przez Fryderyka Wilhelma. Za osadzonym w areszcie w Poznaniu agentem wstawiał się osobiście elektor Fryderyk Wilhelm, który w liście z 1 czerwca 1655 roku poprosił o pomoc Krzysztofa Opalińskiego ${ }^{18}$. Interwencja brandenburska okazała się skuteczna i sędzia ziemski wschowski Schlichtyng wypuścił w końcu Holsta z więzienia. Jednak cała afera wywołała ogromne wzburzenie szlachty wielkopolskiej i przyczyniła się do wzrostu niechętnych Brandenburgii nastrojów ${ }^{19}$. Przekonał się o tym Władysław Kurtzbach-Zawadzki przybyły 10 czerwca 1655 roku do Poznania z listą miejscowości, które Fryderyk Wilhelm zamierzał obsadzić swoim wojskiem. Nie znajdowały się one wyłącznie na tzw. Correspondenzlinie, łączącej Marchię z Prusami

15 Ibidem, k. 31, J. Szlichtyng do elektora Fryderyka Wilhelma, Środa 3 V 1655 r.

${ }^{16}$ Ibidem, k. 32-32v, K. Opaliński do elektora Fryderyka Wilhelma, Śrem 4 V $1655 \mathrm{r}$.

17 Ibidem, k. 26-27, W. Kurtzbach-Zawadzki do elektora Fryderyka Wilhelma, Środa 24 IV/4 V 1655 r.

${ }_{18}$ Ibidem, k. 43-44, Elektor Fryderyk Wilhelm do K. Opalińskiego, Kölln nad Sprewą 1 VI $1655 \mathrm{r}$.

${ }^{19}$ UA, t. 6, wyd. B. Erdmannsdörffer, Berlin 1872, s. 694, Elektor Fryderyk Wilhelm do J. Hoverbecka, Kölln nad Sprewą 11 VII 1655 r. Por. B. Szymczak, Stosunki Rzeczypospolitej z Brandenburgia i Prusami Książęcymi w latach 1648-1658 w opinii i dziataniach szlachty koronnej, Warszawa 2002, s. 132-133. 
Książęcymi. Elektor chciał zająć nie tylko Wieleń, Ujście, Nakło, Pakość, Drahim, ale również Zbąszyń i zamek poznański. Jego apetyty wykraczały poza granice Wielkopolski i sięgały po miejscowości położone na Kujawach $^{20}$.

Wielkopolanie potraktowali wysłannika Hohenzollerna z rezerwą. Uzależnili decyzję o zawarciu układu z dworem berlińskim od zgody króla Jana Kazimierza i porozumienia z nieobecnym nad Wartą starostą generalnym Wielkopolski Bogusławem Leszczyńskim. Dziękowali kurfirstowi za okazanie dobrej woli, dając jednocześnie do zrozumienia, że nie odstąpią wojskom brandenburskim wymienionych miejsc, gdyż sami już je obsadzili. Uważali, że oddziały elektorskie powinny znaleźć się w polu u boku pospolitego ruszenia Wielkopolan ${ }^{21}$.

Krzysztof Opaliński, powiadomiony o przybyciu Kurtzbacha-Zawadzkiego osobiście przez elektora, nie kwapił się również do zacieśnienia związków z Brandenburgią. W tej sytuacji poseł Fryderyka Wilhelma udał się do Leszna, gdzie czekał wraz ze Szlichtyngiem na przyjazd przychylnego Hohenzollernowi starosty generalnego Wielkopolski Bogusława Leszczyńskiego $^{22}$. Według relacji Kurtzbacha-Zawadzkiego skupiona wokół Leszczyńskiego szlachta chętnie widziałaby przymierze z elektorem. Potrzebny był jednak do tego ich protektor. Ten zaś przebywał wciąż daleko od swych dóbr, a powierzone przez sejmik przedsejmowy w Środzie, a następnie sejm obowiązki dowódcy obrony Wielkopolski przekazał sędziemu ziemskiemu wschowskiemu Szlichtyngowi. Sędzia, pełniący także funkcję administratora dóbr Leszczyńskiego, był gorliwym orędownikiem zbliżenia z Fryderykiem Wilhelmem. Musiał wszakże zachowywać się powściągliwie. Był ewangelikiem niemieckiego pochodzenia i nie miał pozycji równorzędnej z Opalińskimi, Grudzińskimi, Gembickimi i innymi rodami magnackimi. Ponadto naraził się niedawno braci szlacheckiej w związku z łagodnym potraktowaniem Holsta. W ten sposób upadły ostatecznie szanse na zawarcie

${ }^{20}$ UA, t.7, s. 369-370, Instrukcja elektora Fryderyka Wilhelma dla W. KurtzbachZawadzkiego, Kölln nad Sprewą 25 V 1655 r.

${ }^{21}$ GStAPK Berlin-Dahlem, I. HA, Rep. 9 (Polen) Nr 5 ee Fasz. 7 b, k. 51-54v, W. Kurtzbach-Zawadzki do elektora Fryderyka Wilhelma, Poznań 18 VI 1655 r.

${ }^{22}$ Ibidem, k. 55-56v, W. Kurtzbach-Zawadzki do elektora Fryderyka Wilhelma, Leszno 20 VI 1655 r. Zob. także UA, t. 7, s. 373. 
brandenbursko-wielkopolskiego przymierza oraz właściwe przygotowanie prowincji do obrony. Protektor Szlichtynga, Bogusław Leszczyński okazał się człowiekiem zupełnie nieodpowiedzialnym. Po zakończeniu 20 czerwca 1655 roku sejmu w Warszawie wyjechał z kraju i zamieszkał we Wrocławiu, gdzie zastała go wiadomość o kapitulacji pospolitego ruszenia Wielkopolan pod Ujściem ${ }^{23}$.

Kurtzbach-Zawadzki śledził te wydarzenia z Leszna aż do końca czerwca 1655 roku, kiedy to wyruszył w drogę powrotną do Berlina. Odmalowywał w czarnych barwach przygotowania wojenne Wielkopolan i wskazywał na coraz większy rozdźwięk między nimi a dworem królewskim w Warszawie, który zachowywał się jego zdaniem tak, jakby nie wierzył w istnienie Szwedów. Nie rozumiał zupełnie, jak można było naznaczać sejmik relacyjny na 20 czerwca w Środzie do Środy na 20 czerwca w sytuacji, gdy większość szlachty szykowała się już do obrony linii Noteci w trzech ustalonych miejscach przed wojskami Karola X Gustawa ${ }^{24}$.

Przygotowania do odparcia agresji szwedzkiej znajdowały się rzeczywiście w opłakanym stanie. Sejmik przedsejmowy, obradujący w Środzie na przełomie kwietnia i maja 1655 roku, nie czekając na sejm, podjął decyzję o powołaniu pospolitego ruszenia, wystawieniu piechoty łanowej i zaciągu trzech tysięcy cudzoziemskiej piechoty u "jakiego przyjaznego Rzeczypospolitej sąsiedniego księcia”, przez co rozumiano wtedy elektora brandenburskiego ${ }^{25}$. Wobec fiaska rozmów z dworem berlińskim nie można było liczyć na użycie ostatniego z wymienionych rodzajów sił zbrojnych. Drugim ciosem, jaki spotkał Wielkopolan, była decyzja skierowania przez króla Jana Kazimierza do województwa kaliskiego dwóch chorągwi kwarcianych pułkownika Jacka Szemberka. Zamiast udzielić wsparcia Wielkopolanom

${ }^{23}$ W. Dworzaczek, Leszczyński Bogustaw, [w:] Polski Słownik Biograficzny (dalej: PSB), t. 17, Wrocław 1972, s. 109; idem, Schlichtingowie w Polsce. Szkic genealogiczno-historyczny, Warszawa 1938, s. 66-67; L. Kubala, Wojna szwedzka, s. 80-82; B. Szymczak, Stosunki Rzeczypospolitej, s. 136.

${ }^{24}$ GStAPK Berlin-Dahlem, I. HA, Rep. 9 (Polen) Nr 5 ee Fasz. 7 b, k. 62-62v, W. Kurtzbach-Zawadzki do elektora Fryderyka Wilhelma, Leszno 29 VI 1655 r.

25 Archiwum Państwowe w Poznaniu (dalej: AP Poznań), Księgi grodzkie poznańskie nr 731, k. 311-315v, Laudum sejmiku województw poznańskiego i kaliskiego, Środa 28 IV 1655 r.; K. Jarochowski, Wielkopolska w czasie pierwszej wojny, s. 12-13. 
zajęły się one grabieniem tamtejszej szlachty. Zagrożeni posiadacze ziemscy odmówili udziału w pospolitym ruszeniu, bojąc się zostawić swoje majątki na łasce rabusiów ${ }^{26} .7$ czerwca 1655 roku Jan Kazimierz odwołał wszystkie chorągwie kwarciane przeznaczone na obronę Wielkopolski i Prus Królewskich przed Szwedami na Ukrainę ${ }^{27}$. Uniwersał króla nie zrobił wszakże wielkiego wrażenia na bandach żołnierskich, które grasowały w okolicach Kalisza jeszcze w lipcu 1655 roku $^{28}$.

$\mathrm{Na}$ domiar złego starosta generalny Wielkopolski i podskarbi wielki koronny Bogusław Leszczyński nie wywiązywał się należycie z powierzonych sobie zadań. Nie pojawił się w ogóle nad Wartą i koordynował przygotowania do obrony prowincji z odległej Warszawy. Stamtąd też wydał 20 maja 1655 roku uniwersał, wzywając szlachtę poznańską i kaliską na pospolite ruszenie, „zważywszy wiadomość pewną, że wojska sąsiadów naszych niechętnych zbliżają się ku granicom naszym". Pospolitacy mieli zebrać się w dwóch miejscach 8 czerwca. Obywatele województwa poznańskiego mieli podążyć „przy kasztelanach swoich” do Poznania, do wojewody poznańskiego, obywatele województwa kaliskiego zaś - także pod przewodem kasztelanów - do Nakła, do wojewody kaliskiego ${ }^{29}$. $\mathrm{Na}$ tym uniwersale skończyła się aktywność Bogusława Leszczyńskiego w sferze obrony prowincji. Starosta generalny Wielkopolski - jak już wspomnieliśmy - zdezerterował, każąc się zastąpić pozbawionym posłuchu wśród szlachty Szlichtyngiem.

Kłopoty pojawiły się także na najniższym, powiatowym szczeblu, gdzie decydującą rolę odgrywali kasztelanowie. W myśl laudum średzkiego z 28 kwietnia 1655 roku kasztelanowie, wraz z wyznaczonymi „do swego boku” dwoma lub trzema deputatami, mieli najpóźniej 20 maja zjechać do wskazanych w uchwale grodów i tam w ciągu czterech dni, to jest do

26 W. Dworzaczek, Od najazdu szwedzkiego do trzeciej wojny pótnocnej, [w:] Dzieje Wielkopolski, t. 1 (do roku 1793), pod red. J. Topolskiego, Poznań 1969, s. 683.

${ }^{27}$ AP Poznań, Księgi grodzkie wschowskie nr 144, k. 491-492, Księgi grodzkie kcyńskie nr 101, k. 188v-189, Uniwersał króla Jana Kazimierza, Warszawa 7 VI 1655 r.

${ }_{28}$ W. Dworzaczek, Od najazdu szwedzkiego, s. 683.

${ }^{29}$ AP Poznań, Księgi grodzkie wschowskie nr 144, k. 487v-488 i nr 169, k. 41v, Księgi grodzkie kcyńskie nr 101, k. 165-166, Uniwersał B. Leszczyńskiego generała wielkopolskiego do województwa poznańskiego i kaliskiego, Warszawa $20 \mathrm{~V} 1655$ r. 
24 maja, odebrać za kwitami z rąk miast i szlachty dostarczanych żołnierzy łanowych. Ostateczny termin powierzonego kasztelanom i deputatom zadania upływał 30 maja, kiedy to mieli oni przekazać zebranych żołnierzy łanowych wybranym przez sejmik rotmistrzom powiatowym. Uchwałę sejmiku średzkiego w tej kwestii zlekceważył całkowicie kasztelan śremski Przecław Leszczyński, który nie stawił się w Kościanie i nie odebrał ściągającej do grodu piechoty łanowej. Mało tego, był także nieobecny na popisie pospolitego ruszenia powiatu kościańskiego i nie wziął później udziału w wyprawie pod Ujście ${ }^{30}$.

Przecław Leszczyński znalazł przypuszczalnie kilku naśladowców. Podczas kwerend w księgach grodzkich z 1655 roku nie natrafiliśmy bowiem na żaden przekaz świadczący o udziale w organizacji obrony Wielkopolski na szczeblu powiatu kasztelana przemęckiego Adama Rozdrażewskiego, kasztelana nakielskiego Mikołaja Korycińskiego i kasztelana gnieźnieńskiego Krzysztofa Gembickiego. Nie można wszakże roztaczać złej opinii na temat wszystkich członków interesującej nas grupy senatorów wielkopolskich. Niektórzy kasztelanowie, mimo rozmaitych przeszkód, starali się wykonać swoje obowiązki. Jednym z nich był kasztelan lędzki Zygmunt Łaszcz ze Strzemielca, który przybywszy wraz z deputatami 20 maja do Konina, nie zastał tam „żadnej gotowości”. Wobec braku zapału wojennego mieszkańców podporządkowanego sobie powiatu Łaszcz zdecydował się na przeniesienie terminu odbioru zbrojnych pachołków na 28 maja $^{31}$. I ten termin nie został dotrzymany. Pierwsi żołnierze łanowi pojawili się bowiem przed kasztelanem lędzkim dopiero 30 maja $^{32}$.

Więcej szczęścia miał kasztelan kamieński Andrzej z Bnina Starkowiecki, który 31 maja 1655 roku wspólnie z deputatami: burgrabią kcyńskim Stanisławem Kowalskim i Marcinem Gałczyńskim oblatował terminowe odebranie drabów piechoty łanowej w księgach grodzkich w Kcyni ${ }^{33}$. Nie wiemy natomiast nic o wysiłkach Starkowieckiego w kwestii wyprawie-

30 W. Dworzaczek, Leszczyński Przectaw Pawet, [w:] PSB, t. 17, s. 127.

31 AP Poznań, Księgi grodzkie konińskie nr 64, k. 117 v, Z. Łaszcz kasztelan lędzki do obywateli powiatu konińskiego, Konin $20 \mathrm{~V} 1655$ r.

${ }^{32}$ Ibidem, k. 125-127, 131-131 v, 137 b.

33 AP Poznań, Księgi grodzkie kcyńskie nr 101, k. 169. 
nia pospolitego ruszenia powiatu kcyńskiego na zjazd wyznaczony przez starostę generalnego Wielkopolski na 8 czerwca do Nakła.

Najlepiej udokumentowane są działania kasztelana biechowskiego Mikołaja Szołdrskiego. Po terminowym zebraniu żołnierzy łanowych, 30 maja 1655 roku, Szołdrski wyznaczył zjazd pospolitego ruszenia powiatu pyzdrskiego na 6 czerwca w Pyzdrach. Miało ono wyruszyć „ku Nakłu” już 7 czerwca i osiągnąć punkt zborny nazajutrz, 8 czerwca $^{34}$.

Wobec absencji szlachty powiatu kaliskiego, spowodowanej - jak już wspomnieliśmy - rabunkami żołnierzy kwarcianych oraz wskazanymi opóźnieniami mobilizacyjnymi powiatu konińskiego, zjazd pospolitego ruszenia województwa kaliskiego odbył się w bardzo okrojonym składzie. Kadłubowy charakter miał także zjazd pospolitego ruszenia województwa poznańskiego. Wiemy tylko, że uczestniczył w nim kasztelan krzywiński Maksymilian Miaskowski, który 8 czerwca 1655 roku na popisie pod Poznaniem zwolnił od udziału w służbie z powodu podeszłego wieku (ukończone 65 lat) stolnika poznańskiego Stanisława Lipskiego ${ }^{35}$.

Największe opóźnienia mobilizacyjne w województwie poznańskim dotyczyły ziemi wschowskiej. Bezczynność kasztelana przemęckiego Adama Rozdrażewskiego i podporządkowanych mu obywateli tej części Wielkopolski wywołała w końcu reakcję wojewody poznańskiego Krzysztofa Opalińskiego. Uniwersałem wysłanym 20 czerwca 1655 roku z Sierakowa powiadomił on szlachtę ziemi wschowskiej o gromadzeniu się wojska szwedzkiego u ujścia Odry i wiszącym nad Wielkopolską niebezpieczeństwie najazdu. NawoływałMonitował ją do stawienia się 27 czerwca pod Wschowę i wyruszenia stamtąd „zaraz do obozu, który zaraz pod Ujściem zatoczony będzie (gdzie mnie w.m.m. panowie już zastaniecie) bez żadnej zwłoki”"

${ }^{34}$ AP Poznań, Księgi grodzkie pyzdrskie nr 85, k. 694v-695, Uniwersał M. Szołdrskiego kasztelana biechowskiego do obywateli powiatu pyzdrskiego, Pyzdry $30 \mathrm{~V} 1655 \mathrm{r}$.

35 AP Poznań, Księgi grodzkie poznańskie nr 731, k. 420v.

36 AP Poznań, Księgi grodzkie wschowskie nr 144, k. 491v-493v, Uniwersał K. Opalińskiego wojewody poznańskiego do obywateli ziemi wschowskiej, Sieraków 20 VI 1655 r. 
Należy przypuszczać, że w północnej Wielkopolsce stawił się jako pierwszy oddział piechoty łanowej dowodzony przez rotmistrza Władysława Michała Skoraszewskiego, który w myśl uchwał sejmiku średzkiego z 28 kwietnia 1655 roku obsadził zamek w Drahimiu i miasto Czaplinek. W ślad za nim pojawiły się w Pile 10 lub 11 czerwca 1655 roku pierwsze oddziały pospolitego ruszenia województwa kaliskiego, pod komendą wojewody kaliskiego Andrzeja Karola Grudzińskiego, siostrzeńca wojewody poznańskiego Krzysztofa Opalińskiego. Grudziński, poinformowany o koncentracji wojsk szwedzkich pod Szczecinem i ich rychłym ataku na Wielkopolskę, podjął energiczne działania na rzecz ściągnięcia do rejonu nadnoteckiego reszty szlachty pozostającej wciąż w domach. Zwrócił się w tym celu 20 czerwca $\mathrm{z}$ wezwaniem do obywateli całego województwa kaliskiego. W wydanym w Pile uniwersale zawarł akcenty pouczające i niepokojące. Wyznaczając termin przybycia reszty pospolitego ruszenia województwa kaliskiego nad Noteć na 27 czerwca, pisał:

\begin{abstract}
Nie widząc tedy inszego sposobu do zapobieżenia tak prędkiej nieprzyjacielskiej inkursji, zdało się do wiadomości w.m. moim miłościwym panom braciom podać, upraszając ichm. moich uczciwych panów o ostatnią już ochotę do ostatecznego ratunku ojczyzny, ażebyście się w.m.m. panowie pro die vigesima septima praesentis stawili, gdzie ja już za bytnością w.m.m. panów niedziel półtory czekam, i dalej za wiadomością w.m.m. panów oczekiwać będę. Daj Panie Boże, aby nas tylko nie uprzedził nieprzyjaciel, acz dawałem ja w.m.m. panom wiedząc o tym niebezpieczeństwie wcześniej znać, ale że się to w.m.m. panom nie zdało, teraz tedy proszę, chciejcie w.m. panowie przynajmniej w tym ostatnim terminie non decesse patriae ${ }^{37}$.
\end{abstract}

Ponaglenia Grudzińskiego dotarły do Kalisza, Kcyni i Konina po kilku dniach, dopingując do działania powiązanych z tymi grodami kasztelanów. 25 czerwca 1655 roku kasztelan kaliski Stanisław na Pogorzeli Pogorzelski wezwał obywateli swego powiatu do stawienia się 30 czerwca w Gnieźnie, "gdzie mnie już w.m.m. Państwo zastaniecie”. Zgromadzeni tam pospoli-

${ }^{37}$ AP Poznań, Księgi grodzkie kaliskie nr 279, k. 1075v-1076, Księgi grodzkie konińskie nr 64, k. 140-140v, Księgi grodzkie kcyńskie nr 101, k. 196, Uniwersał A.K. Grudzińskiego wojewody kaliskiego do województwa kaliskiego, Piła 20 VI 1655 r. 
tacy powiatu kaliskiego, „porządek sami namówiwszy”, mieli podążyć dalej na północ „do obozu, który jest już podobno zatoczony” ${ }^{38}$. Nieco później, bo 28 czerwca, wydał uniwersał kasztelan lędzki Zygmunt Łaszcz, wyznaczając zjazd pospolitego ruszenia powiatu konińskiego na 30 czerwca pod Koninem. Zapowiedział w nim stanowczo, że stamtąd „zaraz ruszymy pod Ujście i Piłę żadnego nie czyniąc popisu, który się już dawno odprawił"39. Przywołał tutaj zatem odbyty 8 czerwca przy słabej frekwencji szlachty popis pospolitego ruszenia województwa kaliskiego w Nakle.

Gorzej rzecz się ma z wiadomościami na temat reakcji kasztelana kamieńskiego Andrzeja Starkowieckiego. Podczas kwerend w księgach grodzkich nie natrafiliśmy bowiem na wydany przez niego uniwersał adresowany do obywateli powiatu kcyńskiego.

Cytowane powyżej apele senatorów wielkopolskich musiały odnieść pewien skutek i spowodować pojawienie się nad Notecią dużych sił zbrojnych. Gromadzenie się reszty pospolitego ruszenia zajęło dwa tygodnie, przykładowo wojewoda podlaski Jan Piotr Opaliński przybył ze swym pocztem do obozu pod Ujściem dopiero 9 lipca ${ }^{40}$. Po ukończeniu całej tej akcji liczebność pospolitego ruszenia stojącego nad Notecią szacowano na około 13 tys. Obok niego znajdowało się jeszcze około 1400 ludzi łanowej piechoty i niewielki zaciąg jazdy. Pod nieobecność starosty generalnego Wielkopolski dowództwo obrony spoczęło w rękach dwóch wojewodów: poznańskiego Opalińskiego i kaliskiego Grudzińskiego. Pierwszy z nich nie miał zupełnie doświadczenia wojskowego i uchodził powszechnie za człowieka pióra i rady, a nie wojny. Wojewodom towarzyszyło co najmniej sześciu innych senatorów wielkopolskich. W źródłach udokumentowana jest obecność pod Ujściem kasztelana poznańskiego Franciszka Sędziwoja Czarnkowskiego, kasztelana kaliskiego Stanisława Pogorzelskiego, kasztelana międzyrzeckiego Pawła Gembickiego, kasztelana krzywińskiego Maksymiliana Miaskowskiego, kasztelana rogozińskiego Wojciecha z Błociszewa

38 AP Poznań, Księgi grodzkie kaliskie nr 279, k. 1074v-1075, Uniwersał S. Pogorzelskiego kasztelana kaliskiego do obywateli powiatu kaliskiego, Pogorzela 25 VI $1655 \mathrm{r}$.

39 AP Poznań, Księgi grodzkie konińskie nr 64, k. 140v, Uniwersał Z. Łaszcza kasztelana lędzkiego do obywateli powiatu konińskiego, Leszcze 28 VI 1655 r.

${ }^{40}$ A. Sajkowski, Krzysztof Opaliński, s. 223. 
Gajewskiego i kasztelana santockiego Wojciecha Miaskowskiego. Grono to uzupełniał jeszcze podkomorzy kaliski Krzysztof Grzymułtowski oraz urzędnicy z innych województw powiązani rodzinnie i majątkowo z Wielkopolską, między innymi wojewoda podlaski Jan Piotr Opaliński, wojewoda inowrocławski Jakub Hieronim Rozdrażewski i starosta inowrocławski Zygmunt Działyński ${ }^{41}$. Z bardzo dużą dozą prawdopodobieństwa możemy stwierdzić, że w obozie nadnoteckim znaleźli się także kasztelan biechowski Mikołaj Szołdrski i kasztelan lędzki Zygmunt Łaszcz.

W świetle przekazów źródłowych Wielkopolanie nie mieli zbyt wiele czasu na przygotowanie obronnych pozycji przed najazdem Szwedów. Nie mogła więc im się sprzykrzyć bezczynność obozowa. Wbrew twierdzeniom Kazimierza Jarochowskiego nie stało się wówczas powszechnym zjawiskiem zwalnianie z obowiązku służby wojskowej przez naczelnych dowódców pospolitego ruszenia ich krewnych i znajomych. Jedyny tego typu przypadek udokumentowany w źródłach dotyczył starościca średzkiego Zygmunta z Grudny Grudzińskiego, który przybył do obozu pod Ujściem z pocztem 100 zbrojnych niemal prosto $\mathrm{z}$ wojaży zagranicznych. Zwolniono go od służby i odesłano do domu 16 lipca 1655 roku z powodu „młodego wieku”. Zgody na to nie wyraził jednak ani Krzysztof Opaliński, ani Andrzej Karol Grudziński, tylko trzej inni dygnitarze przebywający pod Ujściem: wojewoda podlaski Jan Piotr Opaliński, kasztelan poznański Franciszek Sędziwój Czarnkowski i kasztelan kaliski Stanisław Pogorzelski² ${ }^{42}$.

Mimo że wojewodowie poznański i kaliski wywiązywali się - jak dotąd - należycie ze swoich obowiązków, szanse na sukces militarny i odparcie najeźdźców były znikome, jeśli nie żadne. Pospolitacy, a także świeżo zebrana piechota łanowa nie posiadali odpowiedniego przygotowania bojowego. Brakowało również armat i prochu. Jedynym atutem były naturalne walory obronne Ujścia, które stanowił wierzchołek łuku, jaki tworzyła Noteć płynąca wśród bagien od Nakła ku Wieleniowi. Z powodu braku czasu

${ }^{41}$ Lista nazwisk ustalona na podstawie: AGAD, Archiwum Koronne Warszawskie, Dział Szwedzkie 11b nr 21; AP Poznań, Księgi grodzkie poznańskie nr 731, k. 444-445; K. Jarochowski, Wielkopolska w czasie pierwszej wojny, s. 16-17; L. Kubala, Wojna szwedzka, s. 70-71, 77; A. Sajkowski, Krzysztof Opaliński, s. 223-224.

42 AP Poznań, Księgi grodzkie poznańskie nr 731, k. 444-445. Por. K. Jarochowski, Wielkopolska w czasie pierwszej wojny, s. 17. 
nie zdołano jednak w pełni wyzyskać warunków naturalnych, właściwie umocnić całej nadnoteckiej linii obronnej i obwarować wszystkich ważnych przepraw. Kiepskie były też panujące wśród Wielkopolan nastroje. Trzymano się wciąż złudnej nadziei, że jednak uda się dojść w ostatniej chwili do porozumienia ze Szwedami.

Agresor górował nad Wielkopolanami pod względem morale, uzbrojenia, wyszkolenia i liczebności. Korpus szwedzki pod komendą feldmarszałka Arvida Wittenberga dysponował 72 działami. Liczył 17 tys. żołnierzy i składał się z zaprawionych w boju najemników niemieckich oraz weteranów szwedzkich z wojny trzydziestoletniej ${ }^{43}$. Wittenbergowi towarzyszył skonfliktowany z polskim królem magnat, ekspodkanclerzy koronny Hieronim Radziejowski, któremu Jan Kazimierz odebrał kilka lat wcześniej dobra ziemskie, cześć i żonę. Rozwinął on wśród polskich elit politycznych szeroko zakrojoną akcję agitacyjną, wzywając senatorów Rzeczypospolitej do porzucenia nieudolnego władcy i przejścia na stronę szwedzką. Radziejowski był spokrewniony z kilkoma obrońcami obozu pod Ujściem, między innymi wojewodą inowrocławskim Jakubem Hieronimem Rozdrażewskim, któremu przed trzema laty, szykując się do ucieczki, powierzył w testamencie opiekę nad dziećmi ${ }^{44}$. Wszystko to razem wzięte przemawiało na korzyść Szwedów.

Dnia 12 lipca 1655 roku feldmarszałek Arvid Wittenberg i Hieronim Radziejowski wyprawili ze Szczecina listy, w których wezwali Wielkopolan do złożenia broni i przyjęcia szwedzkiej protekcji. Obrońcy nadnoteckich umocnień odpowiedzieli na ten apel 19 lipca, odsyłając Wittenberga i Radziejowskiego do króla Jana Kazimierza, do Rzeczypospolitej,

${ }^{43}$ K. Jarochowski, Wielkopolska w czasie pierwszej wojny, s. 18-19; L. Kubala, Wojna szwedzka, s. 70. Inne dane przytacza Jan Wimmer, który początkowo uważał, że korpus szwedzki liczył nieco ponad 14 tys. żołnierzy (J. Wimmer, Przegląd operacji $w$ wojnie polsko-szwedzkiej 1655-1660, [w:] Wojna polsko-szwedzka 1655-1660, red. J. Wimmer, Warszawa 1973, s. 138), a później sprecyzował te ustalenia, podając, bez kompanii artylerii, liczbę 14800 żołnierzy (idem, Polska - Szwecja. Konflikty zbrojne w XVI-XVIII wieku, Oświęcim 2013, s. 95).

${ }^{44}$ A. Kersten, Hieronim Radziejowski. Studium wtadzy i opozycji, Warszawa 1988, s. 396. 
wreszcie do rezultatu rokowań polsko-szwedzkich rozpoczętych właśnie w Sztokholmie ${ }^{45}$. Zanim posłaniec Wittenberga powrócił do swego wodza spod Ujścia z odpowiedziami uzyskanymi od senatorów wielkopolskich, Szwedzi znajdowali się już w stanie wojny z państwem polsko-litewskim. Korpus Wittenberga wyruszył 15 lipca spod Dąbia w kierunku Drahimia, przemaszerował przez kawałek brandenburskiego Pomorza i 21 lipca przekroczył granicę polską pod wsią Siemczynem, zakładając tegoż dnia obóz w okolicach Czaplinka. Zaledwie Szwedzi przekroczyli granicę, liczący 400 osób oddział piechoty łanowej, dowodzony przez rotmistrza Władysława Michała Skoraszewskiego, opuścił Drahim zbyt daleko wysunięty na północ i w obawie przed odcięciem od reszty wojsk polskich wycofał się nad główną linię obronną - Noteć. Tam znajdowały się trzy punkty obronne Wielkopolan: zamek w Wieleniu, miasteczko Ujście z szańcem przedmostowym oraz o $10 \mathrm{~km}$ wysunięta w kierunku Czaplinka Piła. Na wieść o marszu Szwedów ściągnięto wszystkie siły pod Ujście, pozostawiając w Pile jedynie straż przednią. Zebranych zbrojnych rozłożono na przestrzeni trzech kilometrów na wysokiej południowej terasie doliny Noteci, która naprzeciw miasteczka zwężała się do trzech kilometrów. Założony pod Ujściem obóz chroniony był przez Noteć oraz bagna po obu stronach rzeki. Traktu prowadzącego wśród mokradeł do Ujścia oraz mostów strzegł dodatkowo wielki szaniec położony na kępie, w kącie utworzonym przez wpadającą do Noteci Gwdę. Opatrzony groblą, sześcioma działami i silną załogą czynił przeprawę w tym miejscu bardzo trudną do przebycia. Najsłabszy punkt obrony znajdował się natomiast cztery kilometry powyżej ujścia Gwdy, gdzie dolina Noteci zwęża się do dwóch kilometrów. Tu pod Dziembowem istniała druga, uboczna przeprawa przez Noteć, strzeżona przez mały, słabo obsadzony przez Polaków szańczyk.

Szwedzi zbliżali się nieuchronnie do stanowisk polskich pod Ujściem. Po krótkim postoju pod Czaplinkiem dwoma marszami 23 lipca

45 W. Czapliński, Rola magnaterii i szlachty w pierwszych latach wojny szwedzkiej, [w:] Polska w okresie drugiej wojny pótnocnej 1655-1660, t. 1, s. 153; K. Jarochowski, Wielkopolska w czasie pierwszej wojny, s. 19; A. Kersten, Hieronim Radziejowski, s. 391-395 . 
osiągnęli okolice Wałcza i nazajutrz, spychając bez trudu jazdę pospolitego ruszenia z Piły, dotarli na skraj doliny Noteci. Naprzeciw polskich stanowisk agresor ściągnął przeważającą artylerię i rozpoczął ostrzał. Przez pięć godzin trwała kanonada z dział, aż wreszcie pod wieczór dowodzący obroną szańca na kępie Grudziński dał rozkaz do ewakuacji broniącej go dotąd mężnie piechocie łanowej i wspierającym ją ochotnikom. Szwedzi opanowali szaniec i ogniem dalekonośnej artylerii zaczęli wprowadzać zamieszanie i popłoch wśród mas jazdy polskiej rozłożonej na południowym brzegu rzeki. Na domiar złego Polakom strzegącym głównej przeprawy zaczął dokuczać brak amunicji. Tymczasem Wittenberg, widząc warowność obozu ujskiego i trudności zdobycia głównej przeprawy, wykonał manewr oskrzydlający. Pchnął pod wieczór oddział rajtarów drogą boczną na wieś Dziembowo i uderzył w najsłabszy punkt obrony Wielkopolan. Szwedzi wypłoszyli szybko z szańczyka zaskoczonych pojawieniem się wroga piechurów łanowych i sforsowali przeprawę przez Noteć pod Dziembowem pod osłoną ciemności. Postawiło to pod znakiem zapytania sens dalszej obrony ${ }^{46}$.

W obozie polskim pod Ujściem wybuchła panika. Według relacji Andrzeja Radoszewskiego, spisanej kilka dni po tych wydarzeniach, już na samą wieść, że Szwedzi częściowo otoczyli obóz, szlachta rzuciła się gromadnie do ucieczki ${ }^{47}$. Opuszczeni przez znaczną część pospolitego ruszenia dowódcy obrony nie mieli czasu na targowanie się ze Szwedami. 25 lipca 1655 roku w imieniu szlachty województw poznańskiego i kaliskiego podpisali kapitulację. Oba województwa uznawały Karola X Gustawa za swego króla i pana oraz poddawały całą Wielkopolskę Szwedom. Król szwedzki przejmował dochody należne władcom Polski oraz królewszczyzny. Uzyskał także prawo obsadzenia wojskiem szwedzkim Poznania, Kalisza, Leszna, Międzyrzecza oraz innych miejscowości, które okażą się przydatne do zabezpieczenia panowania. Ponadto do dys-

46 S. Herbst, Wojna obronna 1655-1660, [w:] Polska w okresie drugiej wojny pótnocnej 1655-1660, t. 2, Warszawa 1957, s. 51, 53-54; L. Kubala, Wojna szwedzka, s. 70-74; J. Wimmer, Polska-Szwecja, s. 96.

47 W. Czapliński, Rola magnaterii i szlachty, s. 155; A. Sajkowski, Krzysztof Opaliński, s. 232 . 
pozycji Karola X Gustawa została przekazana piechota wystawiona przez województwa wielkopolskie. W zamian za to strona polska otrzymała od nowego władcy gwarancję poszanowania dotychczasowych przywilejów szlachty i duchowieństwa. Na czele sygnatariuszy aktu znaleźli się dwaj wojewodowie: Krzysztof Opaliński i Andrzej Karol Grudziński. Nie byli oni jedynymi twórcami układu, gdyż pod jego warunkami podpisali się jeszcze czterej inni senatorowie wielkopolscy: kasztelan krzywiński Maksymilian Miaskowski, kasztelan międzyrzecki Paweł Gembicki, kasztelan rogoziński Wojciech Gajewski i kasztelan santocki Wojciech Miaskowski ${ }^{48}$. Aktu ujskiego nie uznało tylko dwóch obecnych w obozie dygnitarzy: wojewoda inowrocławski Jakub Hieronim Rozdrażewski i wojewoda podlaski Jan Piotr Opaliński. Czytamy o tym w jednej relacji: „Wojewoda podlaski zachorował, a wojewoda inowrocławski, lubo cioteczny brat Radziejowskiego, oświadczył, że chce dochować wierności Janowi Kazimierzowi. Pozwolono im na to, bo jeden i drugi wojewoda nie mogli sami o swoich województwach stanowić” ${ }^{49}$.

Akt ujski i kulisy jego zawarcia mają już pokaźną literaturę. Historycy, podejmujący temat kapitulacji Wielkopolan przed Szwedami po Kazimierzu Jarochowskim i Ludwiku Kubali, opierali się jednak na ustaleniach swych poprzedników oraz wyzyskiwali te same co oni relacje staropolskie. Nie wzbogacili więc naszej wiedzy o nowe szczegóły. Nie przeprowadzili też kwerendy w zasobach Archiwum Państwowego w Poznaniu i nie mogli w związku z tym dokonać oceny faktycznego stanu przygotowań Wielkopolski do obrony przed Szwedami. Analiza zgromadzonych przeze mnie materiałów źródłowych wskazuje wyraźnie na to, że szlachta wyprawiwszy pod broń piechurów łanowych, nie spieszyła się sama do wojaczki.

48 AGAD, Archiwum Koronne Warszawskie, Dział Szwedzkie 11 b nr 21, k. 1-3, Warunki układu zawartego między marszałkiem polnym Wittenbergiem a podkanclerzym koronnym Hieronimem Radziejowskim, wojewodą poznańskim Krzysztofem Opalińskim, wojewodą kaliskim Andrzejem Karolem Grudzińskim, Ujście [25] VII 1655 r. Na kopie tego dokumentu w języku niemieckim i łacińskim natrafiłem także w Tajnym Archiwum w Berlinie. Zob. GStAPK Berlin-Dahlem, I. HA, Rep. 9 (Polen) Nr 5 ee Fasz. 1 A, k. 17-20.

${ }^{49}$ Cyt. za L. Kubala, Wojna szwedzka, s. 75. 
To właśnie ona spowodowała duże opóźnienia mobilizacyjne, odwlekając jak tylko można, mimo wezwań wojewodów, swój udział w wyprawie pospolitego ruszenia. $\mathrm{Na}$ tle mas szlacheckich dobrze prezentują się dwaj wojewodowie wielkopolscy, którzy dążyli konsekwentnie do zgromadzenia w pasie nadnoteckim jak największych sił zbrojnych.

Większość historyków skupiała się dotychczas na ocenie postępowania Krzysztofa Opalińskiego, widząc w nim głównego sprawcę zdrady. Czy było tak naprawdę? W świetle przeprowadzonej analizy wydaje się, że to zachowanie szlachty utwierdziło zarówno Krzysztofa Opalińskiego, jak i Andrzeja Karola Grudzińskiego w przekonaniu, że wszelki opór jest bezcelowy. W niniejszym artykule staraliśmy się wykazać, że odpowiedzialność za kapitulację należy rozłożyć solidarnie na wszystkie siły polityczne, zaczynając od króla Jana Kazimierza. Warto również przypomnieć, że kluczową rolę w demontażu przygotowań do obrony Wielkopolski przed Szwedami odegrali nieobecni pod Ujściem Leszczyńscy, przede wszystkim starosta generalny Wielkopolski i podskarbi wielki koronny Bogusław. Odpowiedź na pytanie, czym było to spowodowane, daje nam Hieronim Radziejowski. Magnat ten od pierwszej rozmowy z Wielkopolanami przed okopem pod Ujściem odgrażał się Leszczyńskim, zwłaszcza Bogusławowi, zapowiadając, iż splądruje ich dobra, spali Leszno, mszcząc się za to, że przyczynili się do jego upadku. Ekspodkanclerzy koronny nie ograniczył się tylko do pogróżek. Leszna co prawda nie spalił, ale doprowadził wkrótce do doszczętnego zdewastowania dóbr wojewody łęczyckiego Jana Leszczyńskiego i jego pałacu w Goślinie ${ }^{50}$. O postawie Bogusława Leszczyńskiego i jego krewnych zadecydowała zatem obawa przed dostaniem się w ręce Radziejowskiego i rewanżem z jego strony. Znamienne jednak, że Leszczyńscy przestali wierzyć w skuteczność obrony Wielkopolski przed Szwedami na wiele tygodni przed kapitulacją pod Ujściem.

Nikt jak dotąd nie zastanawiał się również nad tym, skąd Szwedzi dysponowali wiedzą na temat najsłabszego punktu obrony przepraw przez Noteć. Czy był to rezultat zdrady, czy też owoc dobrze przeprowa-

50 A. Kersten, Hieronim Radziejowski, s. 404-407; L. Kubala, Wojna szwedzka, s. 74,78 . 
dzonego wywiadu wojskowego? Na koniec wydaje się zasadne postawić pod znakiem zapytania dotychczasowe informacje na temat liczebności i stanu przygotowań polskich sił zbrojnych. W jednej z relacji uczestnika wyprawy pod Ujście czytamy: „Nie mieliśmy od innych województw i od Rzeczypospolitej posiłków, nie mogliśmy wstrzymać nieprzyjaciela [...]. Któż winien, że nas nie posiłkowano? Wojnę tę za plotkę rozumiano. Duchowni łanowych nie dali, dział, prochów i ludzi nie przysłano. Trzy chorągwie wołoskie i 12 dział po czasie przybyły, kiedyśmy już wracali" ${ }^{51}$. Podobnej treści usprawiedliwień było znacznie więcej. Czy były to tylko czcze tłumaczenia?

${ }^{51}$ Cyt. za L. Kubala, Wojna szwedzka, s.78. 